\title{
Postprandial effects of calcium phosphate supplementation on plasma concentration- double-blind, placebo-controlled cross-over human study
}

\author{
Ulrike Trautvetter ${ }^{1}$, Michael Kiehntopf ${ }^{2}$ and Gerhard Jahreis ${ }^{1 *}$
}

\begin{abstract}
Background: The aim of the present study was to examine the postprandial calcium and phosphate concentrations after supplementation with pentacalcium hydroxy-triphosphate (CaP).

Methods: Ten men participated in this double-blind, placebo-controlled, cross-over study. The participants were divided into two groups. One group consumed bread enriched with CaP (plus $1 \mathrm{~g}$ calcium/d) and the other group a placebo product for three weeks. After a two week wash-out, the intervention was switched between the groups for another three weeks. Blood samples were drawn at the beginning (single administration) and at the end (repeated administration) of the intervention periods at 0, 30, 60, 120, 180 and 240 min. Between 0 and 30 min, a test meal, with or without CaP was consumed. The plasma concentrations of calcium and phosphate were examined. One participant dropped out due to personal reasons.

Results: CaP supplementation resulted in a significantly higher plasma calcium concentration after 240 min compared to placebo. After repeated CaP administration, the AUC for the increment in plasma calcium concentration was significantly higher compared to placebo.

After single and repeated CaP supplementation, plasma phosphate concentration significantly decreased after 30, 60, 120 and $180 \mathrm{~min}$ compared to $0 \mathrm{~min}$. The placebo administration resulted in significant decreases after 30,60 and $120 \mathrm{~min}$ compared to 0 min.
\end{abstract}

Conclusion: Our results show that CaP contributes to an adequate calcium supply, but without increasing the plasma concentration of phosphate.

Trial registration: www.clinicaltrials.gov; NCT01296997

Keywords: Calcium phosphate, Plasma calcium, Plasma phosphate, Human study

\section{Background}

Hyperphosphatemia is recognized as a risk factor for mortality in chronic kidney disease [1]. In addition, serum phosphate concentration within the upper limits of normal is associated with a greater prevalence of vascular and valvular calcification in patients with moderate chronic kidney disease [2]. In the last years, our research group performed human studies involving calcium

\footnotetext{
* Correspondence: b6jage@uni-jena.de

'Department of Nutritional Physiology, Institute of Nutrition, Friedrich Schiller University of Jena, Dornburger Straße 24, Jena D-07743, Germany Full list of author information is available at the end of the article
}

phosphate supplementation [3-5]. Most studies with calcium phosphate focus on the beneficial effects relating to intestinal metabolism, e.g. bile acid metabolism, fatty acid excretion, and modulation of the microbiota [5-8]. This is because amorphous calcium phosphate is formed in the human gut and, moreover, is able to precipitate intestinal substances, such as bile or fatty acids $[6,7,9]$. However, calcium phosphate is poorly absorbed in the gut. Evidence comes from studies showing unchanged fasting plasma concentrations of calcium and phosphate after calcium phosphate supplementation [4]. Nevertheless, measuring fasting concentrations is not a convincing

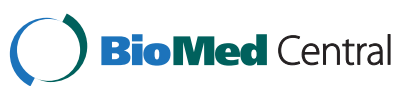


method to examine the influence of calcium phosphate supplementation on calcium and phosphate status. Furthermore, Heaney et al. showed that solubility of a calcium supplement has very little influence on its absorbability and that absorption of calcium from food sources is determined mainly by other food components [10]. In addition, it is necessary to test every calcium product for absorbability [11]. Therefore, in this human study, we examined the postprandial calcium and phosphate concentrations after calcium phosphate supplementation of both a single dose and after three weeks.

\section{Methods}

\section{Supplement}

For purposes of supplementation, we used pentacalcium hydroxy-triphosphate $\left(\mathrm{Ca}_{5}\left(\mathrm{PO}_{4}\right)_{3} \mathrm{OH} ; \mathrm{cfb} ;\right.$ Budenheim Germany; $\mathrm{CaP}$ ) in this study. $\mathrm{CaP}$ was incorporated in whole wheat bread to achieve an additional calcium intake of $1 \mathrm{~g} / \mathrm{d}$ ( $0.5 \mathrm{~g}$ phosphorus/d). Participants consumed approximately $135 \mathrm{~g}$ of this bread daily. Placebo bread was prepared in exactly the same way, but without the CaP supplement.

\section{Subjects}

The study was conducted between July and September 2010 in the Institute of Nutrition, Department of Nutritional Physiology at the Friedrich Schiller University Jena. Ten omnivorous men participated in this doubleblind, placebo-controlled, cross-over study. Eligibility criteria for participants included age between 20 and 35 years and good physical health. A further criterion was that participants remain at the blood withdrawal centre for at least 5 hours between 7.30 am till $12.30 \mathrm{pm}$. Volunteers were provided with detailed information regarding purpose, course, and possible risks involved in the study. All participants gave their written informed consent. The study protocol was approved by the Ethical Committee of the Friedrich Schiller University, Jena (No.:2833-05/10). Of the initial ten volunteers, one participant dropped out due to personal reasons. The main study outcomes comprised blood concentrations of calcium and phosphate (Figure 1).

\section{Study design}

Participants were divided into two groups. For a period of three weeks, one group consumed bread containing $\mathrm{CaP}$ whereas the other group consumed the placebo product. This was followed by a two-week wash-out phase. Thereafter, the intervention changed between the two groups for a further three weeks. Thus, the study design allowed that every participant was his own control. The intervention periods are divided in two parts. At the beginning the participants ate the test bread with or without $\mathrm{CaP}$ onetime and then blood was

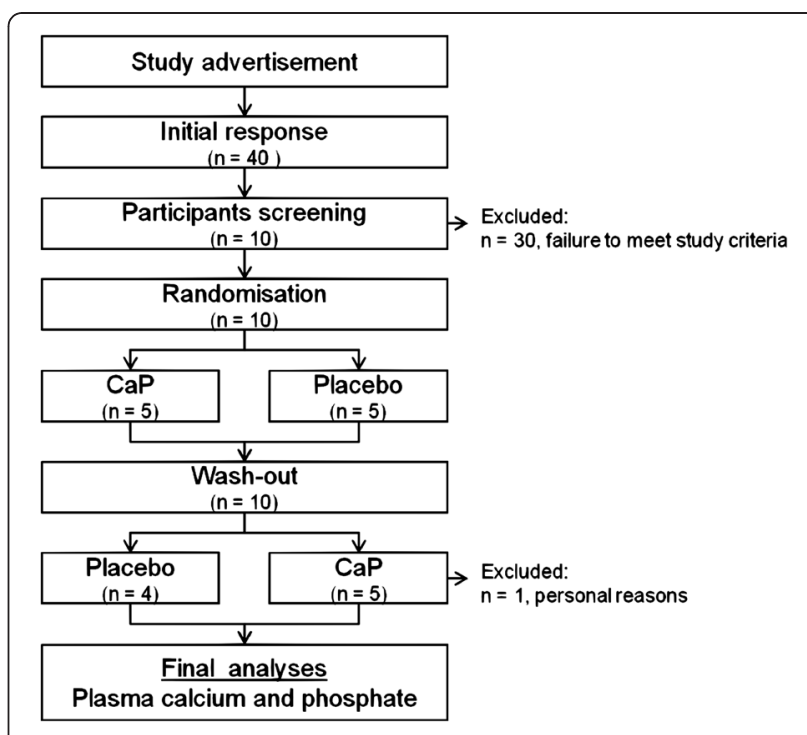

Figure 1 Study flowchart. CaP: pentacalcium hydroxy-triphosphate.

taken (single administration). Afterwards the participants consumed the test bread three weeks daily and then blood was taken again (repeated administration). Consequently, the study involved four types of administrations: single $\mathrm{CaP}$ administration, single placebo administration, repeated $\mathrm{CaP}$ administration and repeated placebo administration. In addition, participants consumed a defined diet for three days before each blood sample was taken (Figure 2).

The defined diet containing the complete food supply for three days was prepared and pre-weighed in the study centre. The subjects were instructed to consume no other foods than provided. Any food residues were weighed and food intake was calculated.

On the day of blood withdrawal, participants came fasting to the Institute of Transfusion Medicine of the Jena University Hospital. Blood samples were drawn

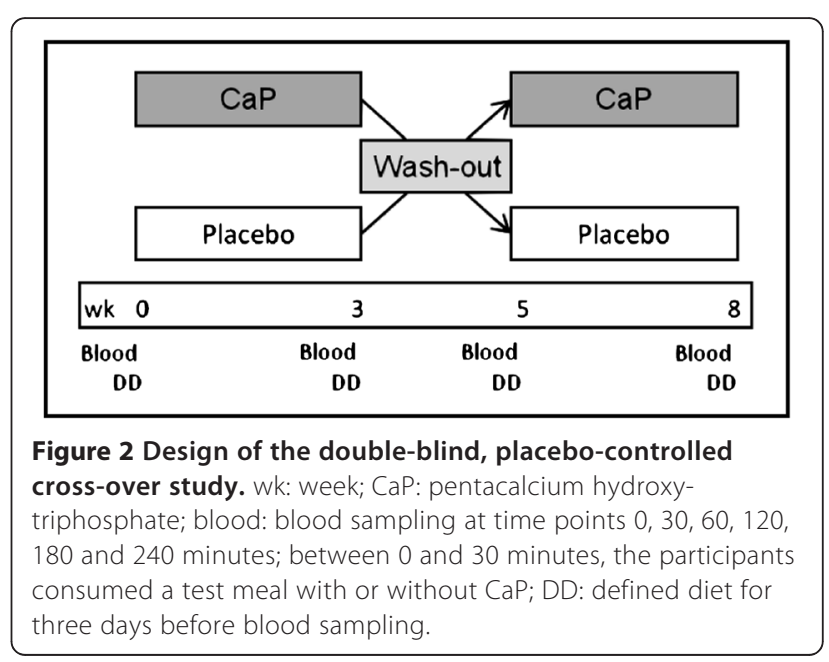


after $0,30,60,120,180$ and 240 minutes, immediately cooled, and transported to the study centre.

Between time point 0 and 30 minutes, the participants consumed a test meal. The test meal consisted of bread with or without $\mathrm{CaP}$ (according to the intervention), $20 \mathrm{~g}$ butter, $25 \mathrm{~g}$ ham, $15 \mathrm{~g}$ sweet hazelnut spread and a banana. During the $240 \mathrm{~min}$ the participants were allowed to drink water ad libitum.

\section{Sample preparation}

Samples of each food component of the defined diet were frozen and stored at $-20^{\circ} \mathrm{C}$ until analysis. Blood was collected in lithium heparin tubes. Plasma was obtained by centrifugation at $2500 \mathrm{x}$ g for 15 minutes at $20^{\circ} \mathrm{C}$. Aliquots were frozen at $-80^{\circ} \mathrm{C}$ until analysis.

\section{Food analysis}

The intake of energy, fat, proteins, and carbohydrates was verified using the Prodi ${ }^{\circledR} 5.4$ software (Nutri-Science $\mathrm{GmbH}$, Freiburg, Germany). For intake of minerals, the respective contents in the provided foods were analysed instead of using the calculation software. Mineral contents of all food samples were determined employing the iCAP 6000 ICP Spectrometer (Thermo Scientific, Waltham, USA). Before analysis, the samples were ashed at $525^{\circ} \mathrm{C}$. The ash was dissolved in $\mathrm{HCl}$ (25\%) and diluted with distilled water.

\section{Analysis of calcium and phosphate}

Calcium and phosphate in plasma were quantified using the autoanalyser ARCHITECT C16000 (Abbott, Illinois, USA) according to the manufacturer's recommendations.

\section{Calculations and statistical methods}

Samples from each participant were coded to protect volunteer identity and to mask treatment groups during the analysis. The areas under the curves (AUC) from 0 to $240 \mathrm{~min}$ were calculated using the trapezoidal method. The calculation based on the increment in plasma calcium and phosphate concentrations.

All values in the text and tables were expressed as mean \pm standard deviation. For reasons of clarity and comprehensibility, values in figures were expressed only as means. Data analysis was performed using the statistical software package PASW Statistics 18 (SPSS Inc., Chicago, USA). Differences were considered significant at $\mathrm{p} \leq 0.05$. The effect of time was tested only to baseline using paired Student's t-test. The effect of supplementation was tested with paired Student's t-test. The sample size for calcium and phosphate was $n=9$.

\section{Results}

Nine subjects completed the four blood samples and test meals. The baseline characteristics and the nutrient intake of the test meal and defined diet are presented in Tables 1 and 2 .

The calcium and phosphorous concentrations of the $\mathrm{CaP}$ bread was $1129 \mathrm{mg} / 135 \mathrm{~g}$ bread and $749 \mathrm{mg} / 135 \mathrm{~g}$ bread, respectively. The placebo bread contained $26 \mathrm{mg}$ calcium/135 g bread and $229 \mathrm{mg}$ phosphorus/135 g bread, respectively.

Following single administration with $\mathrm{CaP}$, calcium concentration increased significantly after $120(\mathrm{p}=0.043)$ and $240 \mathrm{~min}(\mathrm{p} \leq 0.001)$ compared to $0 \mathrm{~min}$. The three week administration of $\mathrm{CaP}$ led to an increase of calcium concentration after $60(\mathrm{p}=0.026), 180(\mathrm{p}=0.011)$ and 240 $(\mathrm{p}=0.001) \mathrm{min}$ compared to $0 \mathrm{~min}$ (Figure 3$)$. Both the single and the repeated administration of $\mathrm{CaP}$ resulted in a significantly higher calcium concentration after $240 \mathrm{~min}$ ( $p=0.005, p=0.006)$ compared to placebo. After repeated administration, the AUC for the increment in calcium concentration was significantly higher after $\mathrm{CaP}$ administration compared to placebo $(\mathrm{p}=0.007)$.

After single and repeated $\mathrm{CaP}$ supplementation, the phosphate concentration significantly decreased after 30 (single: $\mathrm{p} \leq 0.001$, repeated: $\mathrm{p}=0.002$ ), 60 (single: $\mathrm{p} \leq 0.001$; repeated: $p \leq 0.001$ ), 120 (single: $p=0.006$, repeated: $\mathrm{p}=0.006$ ) and 180 (single: $\mathrm{p}=0.043$, repeated: $\mathrm{p}=0.041$ ) min compared to $0 \mathrm{~min}$. The placebo administration resulted in similar significant decreases after 30 (single: $\mathrm{p} \leq 0.001$; repeated: $\mathrm{p}=0.001$ ), 60 (single: $\mathrm{p} \leq 0.001$; repeated: $\mathrm{p} \leq 0.001$ ) and 120 (single: $\mathrm{p}=0.007$; repeated: $\mathrm{p}=0.011) \mathrm{min}$ compared to $0 \mathrm{~min}$.

Following single $\mathrm{CaP}$ and placebo administration, the calcium-phosphorus product significantly decreased compared to 0 (CaP: $2.5 \mathrm{mmol}^{2} / \mathrm{l}^{2}$; placebo: $2.6 \mathrm{mmol}^{2} / \mathrm{l}^{2}$ ) after 30 (CaP: $2.3 \mathrm{mmol}^{2} / \mathrm{l}^{2}, \mathrm{p} \leq 0.001$; placebo: $2.3 \mathrm{mmol}^{2} / \mathrm{l}^{2}$, $\mathrm{p}=0.003), 60$ (CaP: $2.1 \mathrm{mmol}^{2} / \mathrm{l}^{2}, \mathrm{p} \leq 0.001$; placebo: $\left.2.1 \mathrm{mmol}^{2} / \mathrm{l}^{2}, \mathrm{p} \leq 0.001\right), 120$ (CaP: $2.1 \mathrm{mmol}^{2} / \mathrm{l}^{2}, \mathrm{p}=0.006$; placebo: $\left.2.2 \mathrm{mmol}^{2} / \mathrm{l}^{2}, \mathrm{p}=0.008\right)$ and $180\left(\mathrm{CaP}: 2.3 \mathrm{mmol}^{2} / \mathrm{l}^{2}\right.$, $\mathrm{p}=0.049$; placebo: $\left.2.3 \mathrm{mmol}^{2} / \mathrm{l}^{2}, \mathrm{p}=0.031\right) \mathrm{min}$, respectively. After repeated $\mathrm{CaP}$ and placebo administration, the calcium-phosphorus product significantly decreased after 30 (CaP: $2.4 \mathrm{mmol}^{2} / \mathrm{l}^{2}, \mathrm{p}=0.001$; placebo: $2.4 \mathrm{mmol}^{2} / \mathrm{l}^{2}$, $\mathrm{p}=0.001), 60$ (CaP: $2.1 \mathrm{mmol}^{2} / \mathrm{l}^{2}, \mathrm{p}=0.001$; placebo: $\left.2.2 \mathrm{mmol}^{2} / \mathrm{l}^{2}, \mathrm{p} \leq 0.001\right)$ and $120\left(\mathrm{CaP}: 2.1 \mathrm{mmol}^{2} / \mathrm{l}^{2}\right.$, $\mathrm{p}=0.011$; placebo: $\left.2.2 \mathrm{mmol}^{2} / \mathrm{l}^{2}, \mathrm{p}=0.012\right)$ min compared to $0 \mathrm{~min}$ (CaP: $2.6 \mathrm{mmol}^{2} / \mathrm{l}^{2}$, placebo: $2.6 \mathrm{mmol}^{2} / \mathrm{l}^{2}$ ). At

\section{Table 1 Baseline characteristics of participants who completed the study}

\begin{tabular}{lc}
\hline & Subject $(\mathbf{n}=\mathbf{9})$ \\
\hline Age $[\mathrm{y}]$ & $27 \pm 4$ \\
Height $[\mathrm{cm}]$ & $178 \pm 5$ \\
Weight $[\mathrm{kg}]$ & $73.2 \pm 7.5$ \\
BMI $\left[\mathrm{kg} / \mathrm{m}^{2}\right]$ & $23.1 \pm 2.3$ \\
\hline
\end{tabular}


Table 2 Mean nutrient composition of the test meal and the defined diet

\begin{tabular}{|c|c|c|c|c|}
\hline & \multicolumn{2}{|c|}{ Test meal (per meal) } & \multicolumn{2}{|c|}{ Defined (per day) } \\
\hline Energy [MJ] & \multicolumn{2}{|c|}{$2,6 \pm 0,1$} & \multicolumn{2}{|c|}{$10,4 \pm 1,4$} \\
\hline Carbohydrates [g] & \multicolumn{2}{|c|}{$82,1 \pm 3,4$} & \multicolumn{2}{|c|}{$292,9 \pm 41,2$} \\
\hline Fat [g] & \multicolumn{2}{|c|}{$23,5 \pm 0,1$} & \multicolumn{2}{|c|}{$101,6 \pm 19,1$} \\
\hline \multirow[t]{2}{*}{ Protein [g] } & \multicolumn{2}{|c|}{$16,7 \pm 0,3$} & \multicolumn{2}{|c|}{$85,3 \pm 6,3$} \\
\hline & $\mathrm{CaP}$ & Placebo & $\mathrm{CaP}$ & Placebo \\
\hline $\mathrm{Ca}[\mathrm{mg}]$ & $1160 \pm 1$ & $55 \pm 1$ & $2019 \pm 75,2$ & $926 \pm 57$ \\
\hline from $\mathrm{CaP}[\mathrm{mg}]$ & 1104 & 0 & 1104 & 0 \\
\hline$P[\mathrm{mg}]$ & $868 \pm 4$ & $346 \pm 5$ & $2050 \pm 127$ & $1542 \pm 104$ \\
\hline from $\mathrm{CaP}[\mathrm{mg}]$ & 519 & 0 & 519 & 0 \\
\hline
\end{tabular}

$\mathrm{N}=9$; data are expressed as mean \pm standard deviation; CaP pentacalcium hydroxy-triphosphate, $\mathrm{Ca}$ calcium, $P$ phosphorus.

$0 \mathrm{~min}$, the calcium-phosphorus product was significantly higher after $\mathrm{CaP}$ administration compared to placebo administration $(\mathrm{p}=0.031)$.

\section{Discussion}

Calcium has a tightly regulated homeostasis rendering it unsuitable for comparing fasting calcium concentrations for the purpose of determining the effect of supplementation on calcium status. Although, there are some studies in the literature in which the calcium concentration was determined following a short time interval after calcium intake [12-16]. For instance, Heaney et al. compared the bioavailability of calcium from two fortification systems. A combination of tricalcium phosphate and calcium lactate (500 mg calcium, orange juice) led to an increase in serum calcium of almost $0.35 \mathrm{mg} / \mathrm{dl}(0.09 \mathrm{mmol} / \mathrm{l})$ after two hours [14]. In the study of Green et al., the change in the calcium concentration after tricalcium phosphate (1200 mg calcium, powder mixed in water) was $0.1 \mathrm{mmol} / \mathrm{l}$ [12]. In present study, plasma calcium concentration rose by approximately $0.06 \mathrm{mmol} / \mathrm{l}$ in four hours after single administration and by about $0.1 \mathrm{mmol} / \mathrm{l}$ after repeated administration. The significantly higher calcium concentration at 240 min after single and repeated $\mathrm{CaP}$ administration and the significantly higher AUC for the increment in calcium concentration after repeated $\mathrm{CaP}$ administration compared to placebo suggest that part of the calcium from the CaP supplement was absorbed. Supplementation with $\mathrm{CaP}$ led to an increase in blood calcium concentration, which is comparable to other studies.

Because hyperphosphatemia is linked with vascular calcification, cardiovascular mortality, and progression of chronic kidney disease, phosphate intake is an aspect

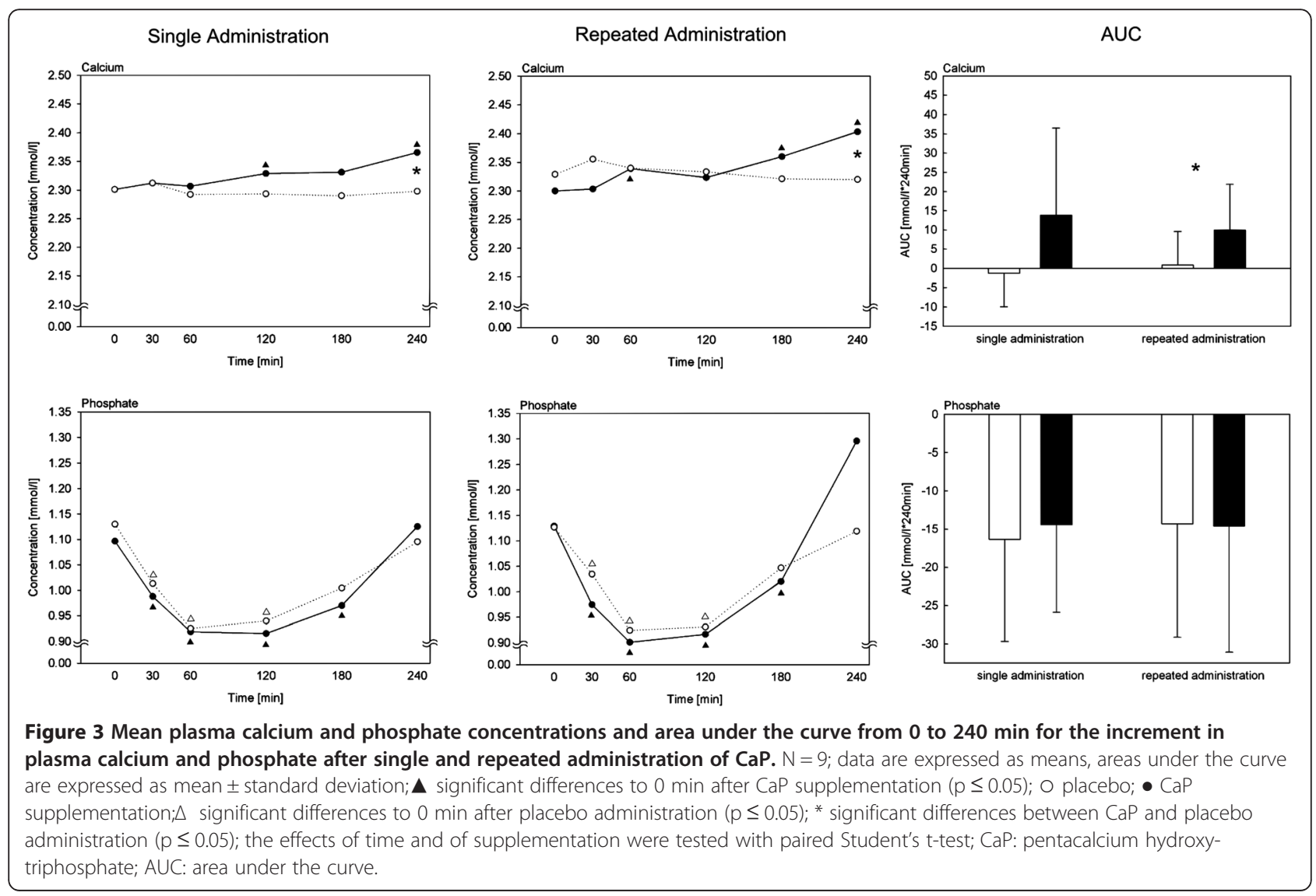


that is controversially discussed [17-19]. In the present study, there was no difference in the plasma phosphate concentration between $\mathrm{CaP}$ and placebo after $240 \mathrm{~min}$. In another study by Reginster et al. comprising 10 male subjects, the serum phosphorus concentration did not change after supplementation with tricalcium phosphate (1000 mg Ca) within a time frame of $360 \mathrm{~min}$ [20]. In contrast, both Yang et al. and Shires et al. showed an increase in phosphorus concentration after an intake of $1200 \mathrm{mg}$ calcium [21,22].

Interestingly, after all administrations (single $\mathrm{CaP}$ and placebo administration, repeated $\mathrm{CaP}$ and placebo administrations), phosphate concentration significantly decreased at first, followed by a rise to basal concentration (Figure 2). Karp et al. showed similar results for plasma phosphate concentration after supplementation with different calcium supplements and potassium citrate [23]. Because of a decrease in bone resorption, the authors assumed a decrease in the release of phosphate from bone for potassium citrate only [23]. Moreover, hypophosphatemia can be a result of phosphate shifts from the blood into the cells, such as after ingestion of glucose, fructose, and feeding following starvation (phosphorylation processes) [24]. A glucose load can induce a transient reduction in serum phosphate levels [24], probably due to secretion of gastrointestinal hormones and subsequent stimulation of calcitonin [25]. Calcitonin induces an inhibition of osteoclasts and a reduction in the release of phosphorus from bone into blood. However, the association between gastrointestinal hormones and calcitonin has only been shown in rodents and not in humans [26].

Alternatively, the decreasing concentration of phosphate in the present study can also be explained by a dilution effect as participants were allowed to drink water ad libitum after the test meal. Between time points $60-120 \mathrm{~min}$, the phosphate concentration increased again to baseline levels indicating that intestinal phosphate absorption took place within this time frame. Indeed, in the study by Karp et al., the participants were also allowed to drink water ad libitum [23]. In contrast, studies in which liquid intake were restricted showed either an immediate increase or a constant phosphate concentration [20-22].

Hence, the present results indicate that the increased phosphate intake due to the CaP supplementation, did probably not lead to an increased phosphate absorption in the gut. This conclusion is supported by comparably postprandial phosphate concentrations and the similar AUC for the increment in phosphate concentration after $\mathrm{CaP}$ and placebo administrations. In order to confirm these results, isotopic tracer studies are indicated. However, the results show that phosphate from this $\mathrm{CaP}$ supplement did not lead to an increase in plasma phosphate concentration.

\section{Conclusion}

In conclusion, our results show that $\mathrm{CaP}$ contributes to an adequate calcium supply, but without increasing the plasma concentration of phosphate. Indeed, the major part of the phosphate from the $\mathrm{CaP}$ supplement is precipitated as amorphous calcium phosphate in the human gut, an aspect that has been shown in several human studies $[3,5,27,28]$.

\section{Abbreviations}

CaP: Pentacalcium hydroxy-triphosphate; AUC: Area under the curve.

\section{Competing interests}

The authors declare that they have no competing interests.

\section{Authors' contribution}

UT conducted research, wrote the manuscript and performed statistical analysis; UT and MK analysed data; UT and GJ designed research and had primary responsibility for final content. All authors read and approved the final manuscript.

\section{Acknowledgements}

We thank VCI (Verband der Chemischen Industrie e.V.) for financial support and for supplying the supplement. The study sponsor was not involved either in data interpretation or in authoring the manuscript. Technical assistance from Ute Helms is greatly appreciated. We thank Nasim Kroegel for language editing.

\section{Author details}

${ }^{1}$ Department of Nutritional Physiology, Institute of Nutrition, Friedrich Schiller University of Jena, Dornburger Straße 24, Jena D-07743, Germany. ${ }^{2}$ Institute of Clinical Chemistry and Laboratory Medicine, Jena University Hospital, Friedrich Schiller University Jena, Erlanger Allee 101, Jena D-07747, Germany.

Received: 6 December 2012 Accepted: 4 March 2013

Published: 8 March 2013

\section{References}

1. Eddington H, Hoefield R, Sinha S, Chrysochou C, Lane B, Foley RN, Hegarty J, New J, O'Donoghue DJ, Middleton RJ, Kalra PA: Serum phosphate and mortality in patients with chronic kidney disease. Clin J Am Soc Nephrol 2010, 5:2251-2257.

2. Adeney KL, Siscovick DS, Ix JH, Seliger SL, Shlipak MG, Jenny NS, Kestenbaum BR: Association of serum phosphate with vascular and valvular calcification in moderate CKD. J Am Soc Nephrol 2009, 20:381-387.

3. Ditscheid $B$, Keller $S$, Jahreis $G$ : Cholesterol metabolism is affected by calcium phosphate supplementation in humans. J Nutr 2005, 135:1678-1682.

4. Grimm M, Muller A, Hein G, Funfstuck R, Jahreis G: High phosphorus intake only slightly affects serum minerals, urinary pyridinium crosslinks and renal function in young women. Eur J Clin Nutr 2001, 55:153-161.

5. Trautvetter U, Ditscheid B, Kiehntopf M, Jahreis G: A combination of calcium phosphate and probiotics beneficially influences intestinal lactobacilli and cholesterol metabolism in humans. Clin Nutr 2012, 31:230-237.

6. Govers MJ, Van der Meer R: Effects of dietary calcium and phosphate on the intestinal interactions between calcium, phosphate, fatty acids, and bile acids. Gut 1993, 34:365-370.

7. Van der Meer R, Lapre JA, Govers M, Kleibeuker JH: Mechanisms of the intestinal effects of dietary fats and milk products on colon carcinogenesis. Cancer Lett 1997, 114:75-83.

8. Bovee-Oudenhoven I, Van der Meer R: Protective effects of dietary lactulose and calcium phosphate against Salmonella infection. Scand J Gastroentero/ Supp/ 1997, 222:112-114.

9. Ditscheid B, Keller $\mathrm{S}$, Jahreis $\mathrm{G}$ : Faecal steroid excretion in humans is affected by calcium supplementation and shows gender-specific differences. Eur J Nutr 2009, 48:22-30.

10. Heaney RP, Recker RR, Weaver CM: Absorbability of calcium sources: the limited role of solubility. Calcif Tissue Int 1990, 46:300-304. 
11. Rafferty K, Walters G, Heaney RP: Calcium fortificants: Overview and strategies for improving calcium nutriture of the US population. J Food Sci 2007, 72:R152-R158.

12. Green JH, Booth C, Bunning R: Acute effect of high-calcium milk with or without additional magnesium, or calcium phosphate on parathyroid hormone and biochemical markers of bone resorption. Eur J Clin Nutr 2003, 57:61-68.

13. Hanzlik RP, Fowler SC, Fisher DH: Relative bioavailability of calcium from calcium formate, calcium citrate, and calcium carbonate. J Pharmacol Exp Ther 2005, 313:1217-1222.

14. Heaney RP, Rafferty K, Dowell MS, Bierman J: Calcium fortification systems differ in bioavailability. J Am Diet Assoc 2005, 105:807-809.

15. Heller HJ, Greer LG, Haynes SD, Poindexter JR, Pak CY: Pharmacokinetic and pharmacodynamic comparison of two calcium supplements in postmenopausal women. J Clin Pharmacol 2000, 40:1237-1244.

16. Heller HJ, Stewart A, Haynes S, Pak CY: Pharmacokinetics of calcium absorption from two commercial calcium supplements. J Clin Pharmacol 1999, 39:1151-1154

17. Ellam TJ, Chico TJ: Phosphate: the new cholesterol? The role of the phosphate axis in non-uremic vascular disease. Atherosclerosis 2012, 220:310-318.

18. Gonzalez-Parra E, Tunon J, Egido J, Ortiz A: Phosphate: a stealthier killer than previously thought? Cardiovasc Pathol 2012, 21:372-381.

19. Uribarri J: Phosphorus homeostasis in normal health and in chronic kidney disease patients with special emphasis on dietary phosphorus intake. Semin Dial 2007, 20:295-301.

20. Reginster JY, Denis D, Bartsch V, Deroisy R, Zegels B, Franchimont P: Acute biochemical variations induced by four different calcium salts in healthy male volunteers. Osteoporos Int 1993, 3:271-275.

21. Shires R, Kessler GM: The absorption of tricalcium phosphate and its acute metabolic effects. Calcif Tissue Int 1990, 47:142-144.

22. Yang RS, Liu TK, Tsai KS: The acute metabolic effects of oral tricalcium phosphate and calcium carbonate. Calcif Tissue Int 1994, 55:335-341.

23. Karp HJ, Ketola ME, Lamberg-Allardt CJ: Acute effects of calcium carbonate, calcium citrate and potassium citrate on markers of calcium and bone metabolism in young women. Br J Nutr 2009, 102:1341-1347.

24. Berner YN, Shike M: Consequences of phosphate imbalance. Annu Rev Nutr 1988, 8:121-148.

25. Yamada C, Yamada Y, Tsukiyama K, Yamada K, Udagawa N, Takahashi N, Tanaka K, Drucker DJ, Seino Y, Inagaki N: The murine glucagon-like peptide-1 receptor is essential for control of bone resorption. Endocrinology 2008, 149:574-579.

26. Bjerre Knudsen L, Madsen LW, Andersen S, Almholt K, de Boer AS, Drucker DJ, Gotfredsen C, Egerod FL, Hegelund AC, Jacobsen $\mathrm{H}$, et al: Glucagon-like Peptide-1 receptor agonists activate rodent thyroid C-cells causing calcitonin release and C-cell proliferation. Endocrinology 2010, 151:1473-1486.

27. Lapre JA, De Vries HT, Van der Meer R: Dietary calcium phosphate inhibits cytotoxicity of fecal water. Am J Physiol Gastrointest Liver Physiol 1991, 261:G907-912.

28. Van der Meer R, Termont DS, De Vries HT: Differential effects of calcium ions and calcium phosphate on cytotoxicity of bile acids. Am J Physiol 1991, 260:G142-147.

doi:10.1186/1475-2891-12-30

Cite this article as: Trautvetter et al:: Postprandial effects of calcium phosphate supplementation on plasma concentration-double-blind, placebo-controlled cross-over human study. Nutrition Journal 2013 12:30.

\section{Submit your next manuscript to BioMed Central and take full advantage of:}

- Convenient online submission

- Thorough peer review

- No space constraints or color figure charges

- Immediate publication on acceptance

- Inclusion in PubMed, CAS, Scopus and Google Scholar

- Research which is freely available for redistribution 